\title{
Dynamics of Deforestation and Degradation of Forests in the Democratic Republic of Congo from 1990 to 2018
}

\author{
Lutumba Suika Achille, Kebin Zhang*, Christian Jonathan Kouassi Anoma \\ College of Soil and Water Conservation, and Desertification Combating, Beijing Forestry University, Beijing, China \\ Email: achillelutumba@gmail.com, *ctccd@126.com, jkouassi83@yahoo.com
}

How to cite this paper: Achille, L.S., Zhang K.B. and Anoma, C.J.K. (2021) Dynamics of Deforestation and Degradation of Forests in the Democratic Republic of Congo from 1990 to 2018. Open Journal of Ecology, 11, 451-461.

https://doi.org/10.4236/oje.2021.115029

Received: March 26, 2021

Accepted: May 14, 2021

Published: May 17, 2021

Copyright ( 2021 by author(s) and Scientific Research Publishing Inc. This work is licensed under the Creative Commons Attribution International License (CC BY 4.0).

http://creativecommons.org/licenses/by/4.0/

\begin{abstract}
Improving conditions to maintain soil fertility levels by avoiding deforestation would require an assessment of the contribution of forests to soil regeneration in complex and unpredictable farming systems involving alternating slash-and-burn farming. Results on forest cover over the period 1990-2018 indicate a net annual deforestation rate of $2.12 \% \pm 0.07 \%$ and $0.12 \%$ annual degradation. The rate of deforestation is estimated mainly in relation to dense forests. Deforestation is the degradation that seems relatively important for DR Congo with relative population densities or the demand for agricultural land is greater which will lead to several consequences such as climate change, soil erosion, biodiversity loss, $\mathrm{CO}_{2}$ emissions, and natural disasters.
\end{abstract}

\section{Keywords}

Deforestation, Natural Disaster, Climate Change, Soil Regeneration, Dense Forests

\section{Introduction}

Forest is defined as an area occupied by ecosystems where the minimum density of tree cover is 10 percent, with a height of more than 3 meters, usually associated with flora and fauna, on natural soils. From a botanical point of view, a forest is a plant formation, characterized by the importance of the tree layer, but also includes shrubs, low plants, climbers and epiphytes [1]. Many forest trees live in symbiosis with fungi and other microorganisms, and many depend on animals for the transport of pollen, seeds or propagules [2]. From an ecological point of view, the forest is a complex and rich ecosystem, offering many habitats to many species and populations of animals, plants, fungal and microbial main- 
taining, for the most part, interdependence relationships [1]. Forest degradation is defined by changes that negatively affect forest population, particularly reducing production capacity (quantity, quality and volume). Therefore, forest degradation is not to be confused with deforestation.

Tropical ecosystems are the main source of emissions due to land-use change and the greatest uncertainty is that emissions come from African rainforests [2]. More than $99 \%$ of the forest area in the Congo Basin area is made up of primary or regenerated as opposed to plantations [4]. Today, these forests, like many others around the world, are being de-deeded and degraded resulting in a fragmentation of the landscape, and the consequences of which are not only for ecosystems but also for the way of life of local people are becoming increasingly critical. This loss is also one of the causes of climate change that currently threatens the survival of the human species on the planet [5]. Deforestation and forest degradation are two phenomena that under the basis of the implementation of a new economic incentive instrument adopted at the 13th Conference of the Parties (COP-13) of the United Nations Framework Convention on Climate Change, held in Bali in 2007 [6]. DRC is firmly committed to reducing emissions from deforestation and forest degradation (REDD) [7]. In the Democratic Republic of Congo, there is still no national consensus on the drivers of deforestation and forest degradation.

Changes in land use, such as deforestation and forest degradation, are a major source of global carbon dioxide emissions after the burning of fossil fuels [8]. Deforestation in Africa and mainly in the Democratic Republic of Congo is a poorly measured phenomenon. Forest ecosystems in the Democratic Republic of Congo contain nearly half of Africa's dense, wet tropical forests. This resource is under increasing pressure from commercial or artisanal logging, slash-and-burn itinerant agriculture, firewood harvesting, mining and urban centre expansion [9]. Deforestation, which leads to a reduction in forest cover in favour of other land use and use, is the result of multiple causes. These causes are often controversial, and impacts, depending on local conditions, can be more or less intense depending on the area. It is also worth noting the difficulty of assessing the direct factors of deforestation, and indirect factors related to other underlying issues may be in fact responsible for deforestation. Thus, logging can be carried out according to principles of sustainable management but generate indirect effects; for example, opening forest trails can eventually lead to their permanent or itinerant use by farmers seeking land to be cleared for their livelihoods. The attribution of deforestation to direct or underlying causes can, if not taken precautions, produce double-counting in the overall estimate of deforestation [10].

Deforestation corresponds to a clear conversion of forest land to other uses with a reduction in forest cover to a density of less than 10 percent.

Deforestation and degradation are not evenly distributed throughout the country, and it is worth noting the existence of "hot spots" of deforestation, particularly on the edge of major cities in the Savanicole strip (Kinshasa, Lubumbashi, Kananga) as well as in the Bowl (Kisangani, Kindu), in the North of the Province of 
Ecuador as well as in the Albertin Rift area (North and South Kivu Eastern, Eastern Province) [7]. The Democratic Republic of Congo (DRC) is the border of deforestation in Africa [11] where 22 billion metric tons of carbons are stored in living biomass its forests and forested savannahs [12]. Rapid deforestation here will not only lead to loss of local ecosystem services and goods, but it can also lead to significant carbon emissions.

The consequences of deforestation are many. In the Democratic Republic of Congo, the plundering of the forest and the clear cuts caused by the increase in logging roads and the devastation of the forest could lead to the loss of $40 \%$ of the forest cover.

The three main drivers of deforestation and degradation cited by the study are agriculture commercial (40\%) and food crops (20\%) and the cutting of firewood (20\%). Failure to act quickly, the study asserts that around $10 \%$ of the forest land of the Democratic Republic of Congo is at risk of disappearing by 2030, and 15\% - $20 \%$ by 2050 . Study says deforestation is expected to reduce DRC's forest heritage from 12 to 13 million ha by 2030 [13].

\section{Material and Method}

\subsection{Study Site}

The Democratic Republic of Congo (DRC) is one of the largest countries in Africa, covering 2,345,409 $\mathrm{km}^{2}$. Located straddling Ecuador, it shares nearly 9000 $\mathrm{km}$ of borders with nine countries (South Sudan and central African Republic to the north, Uganda, Rwanda, Burundi, Tanzania to the east, Zambia and Angola to the south, Republic of Congo and the Angolan province of Cabinda to the west). Stretching across Ecuador, the Democratic Republic of Congo enjoys a warm and humid equatorial climate all year round in the Central, and tropical in the south and north with alternating dry and rainy seasons. Rainfall is plentiful and the DRC has $52 \%$ of the continent's total fresh water reserves [14]. It has an extensive, dense and well-distributed water system throughout its territory. It is dominated by the Congo Basin, a $4670-\mathrm{m}$ long river with a flow of $30,000 \mathrm{~m}^{3}$ per second at the mouth, making it the second largest in the world after the Amazon. The relief of the Democratic Republic of Congo is very diverse with a large bowl to the centre and west, bordered to the east and south by high plateaus. The east of the country is dominated by a volcanic chain interspersed with lakes. Vegetation defines three major natural regions: the dense rainforest in the central basin and to the west; dry forests and savannahs in the southern part and on the northern fringe; and mountain ecosystems along the eastern border [15]. The forest, which covers 155 million hectares of the national territory, makes the DRC one of the largest forest countries in the world, with more than half of the forest in the Congo Basin. (Figure 1 and Figure 2)

The Democratic Republic of Congo has 155 million hectares (ha) of forests divided between 4 major ecosystems: dense rainforest, mountain forests, clear forest (Miombo type) and forest-savannah mosaic. All Congolese forests currently 


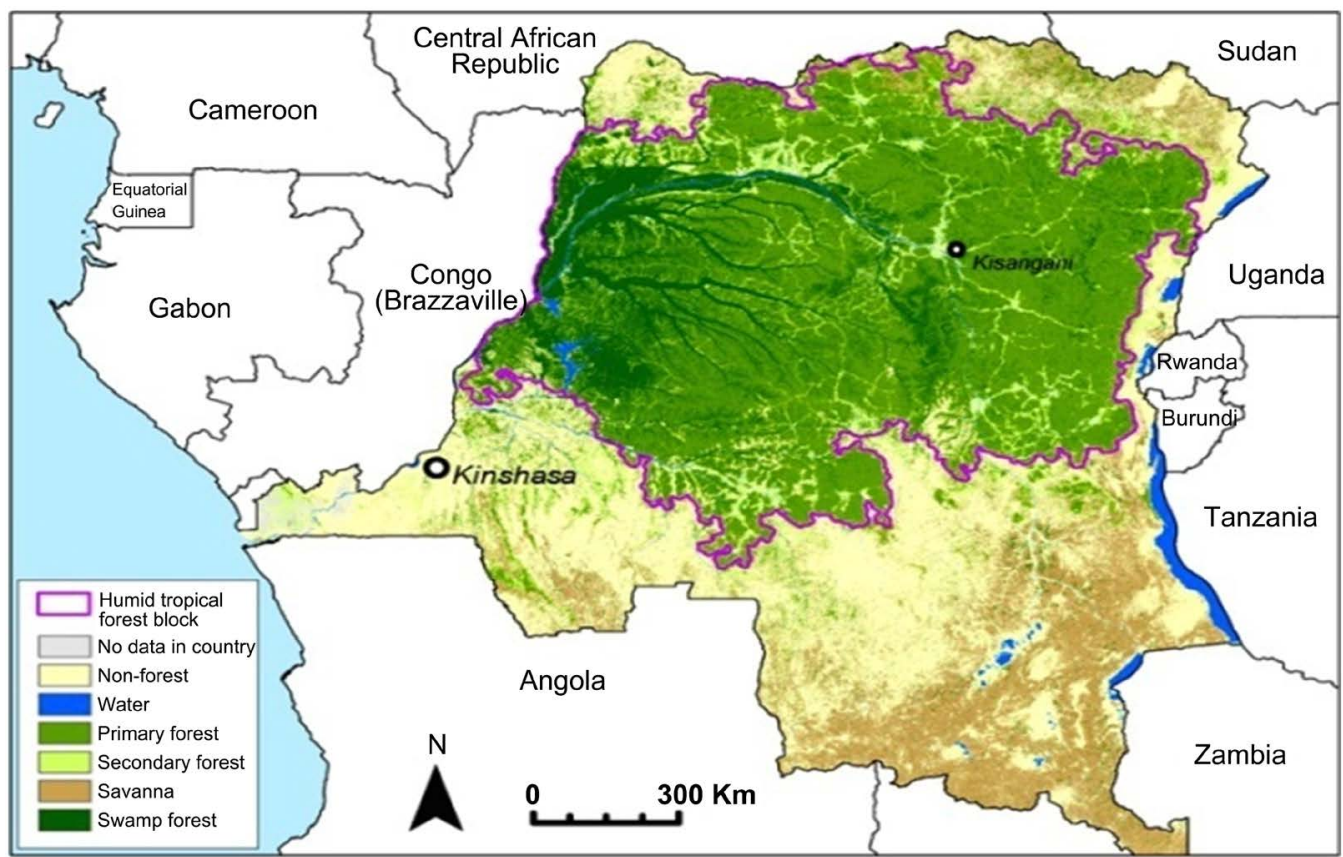

Figure 1. Map showing rainforest cover in Democratic Republic of Congo.

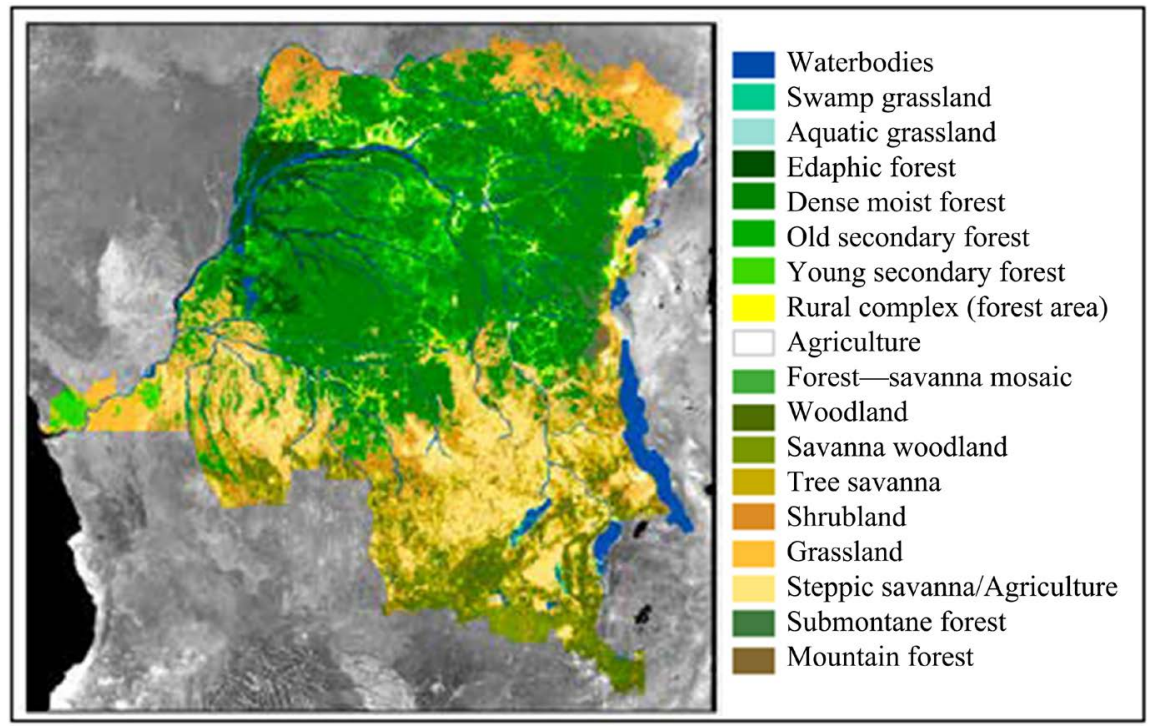

Figure 2. Map showing Democratic Republic of Congo forest cover.

sequester a carbon stock that can be estimated at 40 Gigatonnes (Gt), the equivalent of $140 \mathrm{Gt}$ of potential $\mathrm{CO}_{2}$ emissions (Table 1). The historical deforestation rate has fluctuated between $0.2 \%$ and $0.3 \%$ in the DRC over the last 20 years, which is relatively low compared to the global average $(0.6 \%)$ over the same period [2]. DRC has 19.441 million tonnes of carbon stocks in live forest biomass (Figure 3).

The Democratic Republic of Congo has 155 million hectares of forest [16]. It is the fifth largest forest country in the world and the African country has the largest area of forest, with $47 \%$ of Africa's forest formations. From a regional 
Table 1. Distribution of DRC's forest areas.

\begin{tabular}{ccc}
\hline Type of forest & Area & \\
\cline { 2 - 3 } & $\left({ }^{*} 1000 \mathrm{ha}\right)$ & (\%) P/R Area Forest \\
\hline Low-lying dense forest & 83,762 & 54 \\
Sub-mountain forest $(900-1500 \mathrm{~m})$ & 5995 & 4 \\
Mountain forest (over $1500 \mathrm{~m})$ & 955 & 1 \\
Swamp forest & 8200 & 5 \\
Total wet dense forests & 98,912 & 64 \\
Forest-savannah mosaic & 28,592 & 18 \\
Dense deciduous forest (Miombo) & 28,023 & 18 \\
Total forest-savannah and deciduous forest Dense & 56,615 & 36 \\
Total forest area & 155,527 & 100 \\
\hline
\end{tabular}

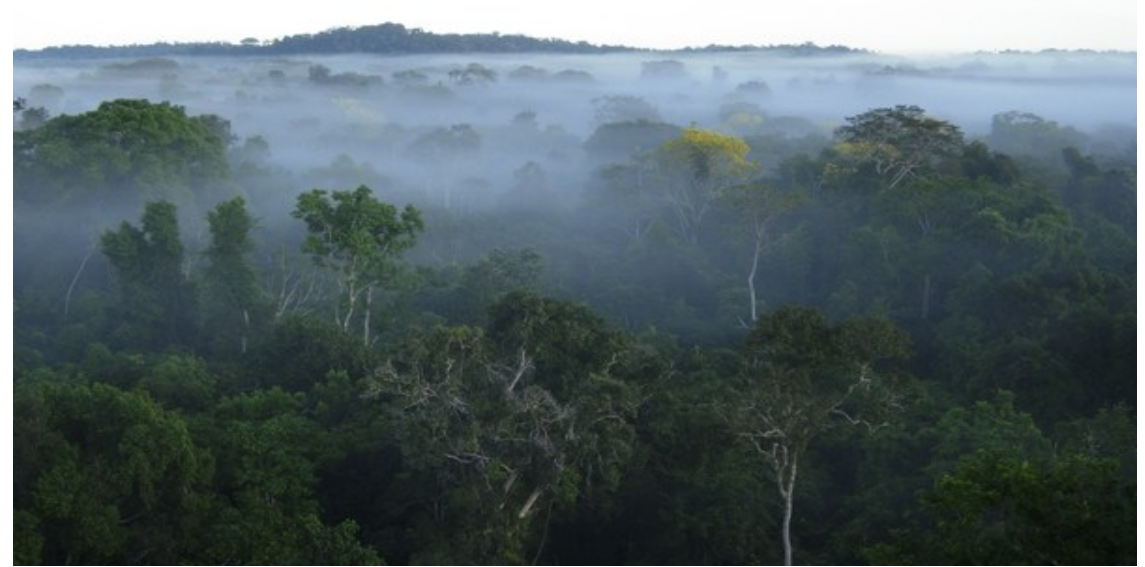

Figure 3. Vegetation of the Democratic Republic of Congo.

point of view, there are more than $60 \%$ of all forests in the Congo Basin. In addition, forests cover $67 \%$ of the national territory [17].

Dense wet forests occupy nearly 99 million hectares, of which just over 83 million are low-lying. It is estimated that 60 million hectares of these forests would be suitable for timber production, roughly equivalent to all other forest countries in Central Africa [18]. These forests are located mainly in the central basin (Figure 4).

\subsection{Material}

We downloaded the corresponding satellite images from the Landsat TM satellite covering the study area for the period from 1990 to 2018.

\subsection{Method}

The method used in this study is an adaptation of the method developed by the 


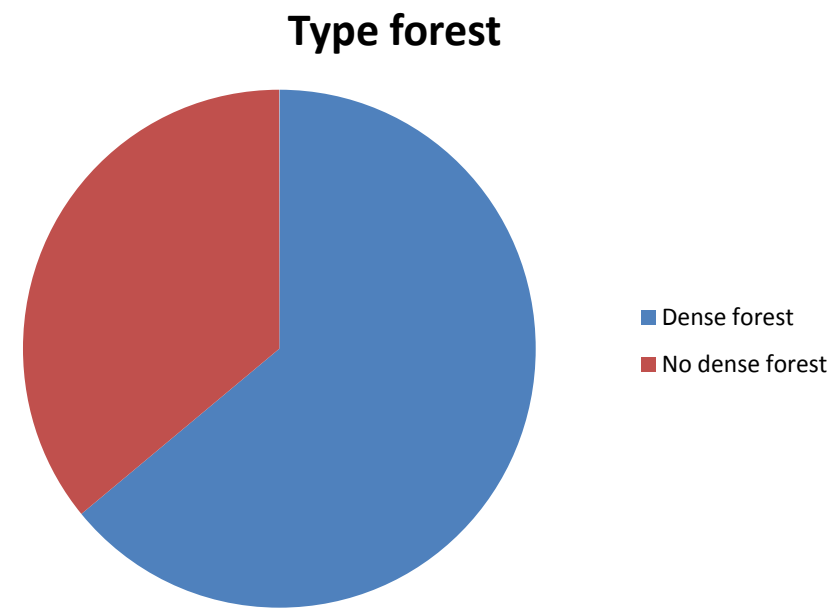

Figure 4. Type forest.

FRA (Forest Resources Assessment) project conducted by FAO. The application of the FRA 1990 method in this study will be based on the use of remote sensing techniques, with the interpretation of high-resolution Landsat TM multidate satellite images of the 1990s as historical images, and 2018s considered to be recent images.

Calculating the rate of deforestation

Equation (1) calculated the rate of deforestation for the period 1990-2018.

In the calculation, the classes "primary forest and degraded secondary forests" were selected as reference classes. The annual rate of deforestation was achieved by dividing the rate of deforestation by the number of years of study (28 years) (Equation (2)) (Equation (1));

$$
\begin{gathered}
T=\frac{(S 2-S 1)}{S} * 100 \\
T \text { an.def. }=\frac{T}{23}
\end{gathered}
$$

- $\quad T$ is the rate of deforestation;

- Tan.def is the annual rate of deforestation;

- $\quad S 2$ is the extent occupied by the forest (mature and secondary) at time 2;

- $\quad S 1$ is the extent occupied by the forest (mature and secondary) at time 1;

- $S$ is the starting area occupied by the forest (mature and secondary).

\section{Results}

Through to the analyzed data we obtained the results presented in Table 2 .

This development points to a risk of the country slipping in the forest transition curve, which would result in a very strong acceleration of the dynamics of loss of forest cover in the coming years, like other tropical countries (Figure 5).

The result of the forest cover estimate in 1990 and the detection of negative change in 2018 give an annual deforestation rate relative to forest area of 2.12\% $\pm 0.07 \%$. Poverty, population growth, weak local (decentralized) governance and 
Table 2. Loss of forest cover in DR Congo from 1990-2018.

\begin{tabular}{ccccccc}
\hline & \multicolumn{5}{c}{ Forest area $(1000$ hectares $)$} \\
\hline Types of forest & 1990 & 2000 & 2005 & 2010 & 2015 & 2018 \\
\hline Primary forest & 105,189 & 104,455 & 104,088 & 103,387 & 102,686 & 101,976 \\
Secondary forest & 55 & 56 & 57 & 58 & 60 & 62 \\
wooded training & 55,118 & 52,737 & 51,547 & 50,689 & 49,832 & 48,978 \\
Total & 160,362 & 157,249 & 155,693 & 154,135 & 152,578 & 151,203 \\
\hline
\end{tabular}

\section{Deforestation rates in DR Congo from 1990-2018}

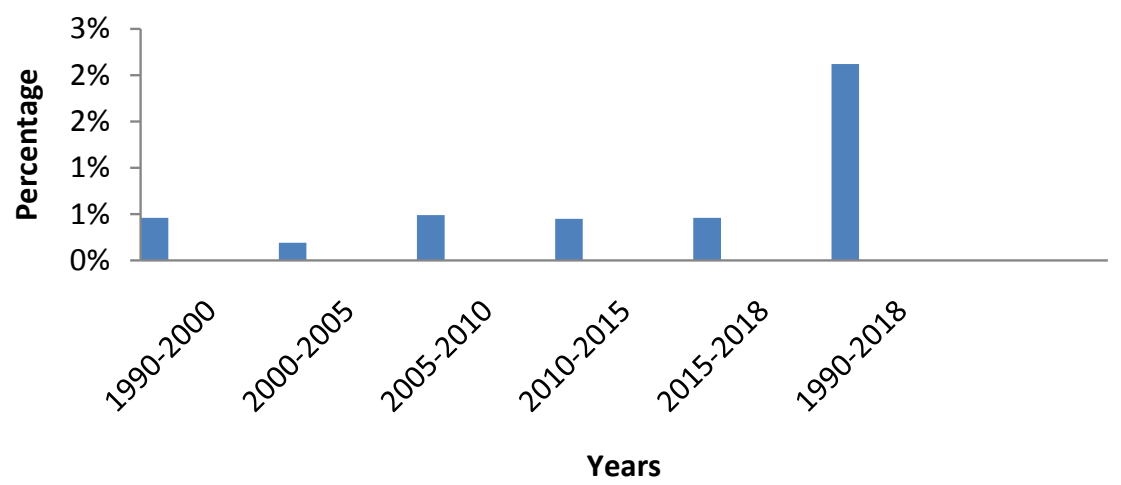

Figure 5. Deforestation rates in DR Congo from 1990-2018.

scarcity of infrastructure (agricultural waste roads) and energy, fuel rural exodus, and are the indirect causes of deforestation.

Agriculture and charcoal production: Currently, the main drivers of deforestation and forest degradation in the Democratic Republic of Congo are food agriculture and charcoal production, which alone destroy more than $90 \%$ of the Democratic Republic of Congo's forests. Firewood collection and logging and mining operations also have an impact. Democratic Republic of Congo's deforestation rates are closely linked to population growth, with nearly two-thirds of the population living in rural areas and producing nearly half of their own food. [19]. Small-scale agriculture appears to be the main driver of deforestation in the Democratic Republic of Congo and other countries in the Congolese basin. However, researchers warn that a "new wave" of industrial deforestation could emerge. If the Congolese basin does nothing to reduce deforestation rates, all forest cover is likely to pass through.

Illegal logging is the second largest factor in deforestation in the Democratic Republic of Congo. It is mainly fuelled by small-scale logging for national and regional markets, and has played a key role in financing the current conflict [20].

Although itinerant cultivation does not necessarily indicate expansion in the primary forest, growing populations can intensify agricultural practices, reducing fallow periods when trees naturally regrow. In 2017, 3\% of the total loss of 
tree cover occurred in protected areas and $10 \%$ in forest concessions [21].

\section{Discussion}

The rate of deforestation over the past 30 years in the Democratic Republic of Congo has always been considered relatively low compared to that of other tropical forest countries. For the period 1990-2000, we estimated at $0.46 \% \pm$ $0.016 \%, 0.19 \% \pm 0.06 \%$ between $2000-2005,0.49 \% \pm 0.01 \%$ between $2005-2010$, $0.45 \% \pm 0.016 \%$ between $2010-2015$, to $0.46 \% \pm 0.016 \%$ between $2015-2018$.

Referring to other authors, for the period 1990-2000, the annual rate of deforestation was at $0.4 \%$ by [22], $0.25 \% \pm 0.06 \%$ by [23] and $0.15 \% \pm 0.02 \%$ by [24]. Between 2000 and 2005, we estimated [24] to bring this rate to $0.32 \% \pm$ $0.05 \%$, twice as much as in the previous decade. Also between 2000 and 2005, [25] report annual deforestation of $0.22 \%$, and $0.25 \%$ for the period $2005-2010$, an increase of $14 \%$ between the two periods. Over the period 2000-2010, [25] reported annual deforestation of $0.23 \%$ (or $3711.8 \mathrm{Kha}$ ). The same research team will report a deforestation rate of $0.27 \%$ (or $5896.3 \mathrm{Kha}$ ) for the period 2000-2012 [26], suggesting a substantial acceleration of deforestation between 2010 and 2012. Finally, in its 3rd national communication in 2015, the DRC reported that the pace of deforestation and forest degradation has remained below the global average of between $0.2 \%$ and $0.3 \%$ over the last 20 years, compared to the global average of $0.6 \%$.

Table 3 and Table 4 illustrate the rate of deforestation and degradation in DR Congo from 1990 to 2018 is estimated at $2.12 \% \pm 0.07 \%$ for deforestation and $0.12 \%$ for degradation.

Table 3. Variation of forest degradation in Democratic Republic of Congo from 1990-2018.

\begin{tabular}{cccc}
\hline Types of forest & 1990 & 2018 & Variation \\
\hline Primary forest & 105,189 & 101,976 & -734 \\
Secondary forest & 55 & 62 & 7 \\
wooded training & $\mathbf{5 5 , 1 1 8}$ & $\mathbf{4 8 , 9 7 8}$ & -6140 \\
Total & 160,362 & $\mathbf{1 5 1 , 2 0 3}$ & -9159 \\
\hline
\end{tabular}

Table 4. Changes in forest cover between 1990-2018.

\begin{tabular}{cc}
\hline$\%$ net annual deforestation (1990-2018) & $\%$ net annual degradation (1990-2018) \\
\hline $2.12 \% \pm 0.07 \%$ & $0.12 \%$ \\
\hline
\end{tabular}

\section{Conclusions}

Levels of deforestation and forest degradation vary widely depending on areas and population density. Despite relatively low historical rates of deforestation over the period 1990-2010 [27], the phenomenon of deforestation has increased sharply in the country in recent years.

In DRC, deforestation accounts for $78 \%$ of greenhouse gas emissions, the cur- 
rent drivers of deforestation in DR Congo are itinerant agriculture on burns, artisanal logging, carbonization and wood energy/firewood, mining, bushfires as the main direct causes of population growth, institutional aspects, infrastructure/urbanization, economic aspects (economic crisis, unemployment, poverty) as the main underlying causes. Preserving the great forest of the Congo River requires massive investment and good supervision of agriculture in order to reduce itinerant agriculture on burns.

The Democratic Republic of Congo is stagnating (up 1\% since 2018 for primary forests). The degradation of biodiversity leads to losses of ecosystem services that were naturally rendered by ecosystems, resulting in economic costs largely unaccounted for and previously ignored in DR Congo. It is essential to put a value on biodiversity and ecosystem services in order to change the trend of loss towards the preservation of biodiversity.

This deforestation results in particular: 1) from the population's heavy dependence on woody energy and low use of alternative energies such as solar, wind, hydro-electric; 2) the widespread practice of itinerant agriculture on Brulis 3) of the anarchic establishment of mining quarries; 4) lack of zoning and forest land use plans agricultural and agricultural; 5) the non-application of the legal and regulatory provisions relating to the sustainable management of forests.

Improving conditions to maintain soil fertility levels by avoiding deforestation would require an assessment of the contribution of forests to soil regeneration in complex and unpredictable farming systems involving alternating slash-and-burn farming. Slash-and-burn agriculture depends on forests to restore soil fertility, but its effects are particularly variable and depend on the situation. The number of variants to be taken into account-soil type, topography, precipitation and human agro-ecological factors-seems to make this assessment an unrealistic proposal at this stage.

At the global level, deforestation and forest degradation account for nearly $20 \%$ of global greenhouse gas emissions, more than the global transport sector, which is why the greenhouse gas emissions balance is crucial in the Amazon and the Congo River basin, where agriculture and deforestation are the major emitters of $\mathrm{CO}_{2}$.

\section{Conflicts of Interest}

The authors declare no conflicts of interest regarding the publication of this paper.

\section{References}

[1] FAO (2003) Gestion durable des forêts tropicales en Afrique centrale, recherche d'excellence. Dép. Forêt série No. 143, 124 p.

[2] MECNT (2009) Potentiel REDD+ de la RDC, Décembre 2009, p. 2.

[3] Ciais, P., Bombelli, A., Williams, M., Piao, S.L., Chave, J., Ryan, C.M., et al. (2012) The Carbon Balance of Africa: Synthesis of Recent Research Studies. Philosophical Transactions of the Royal Society A, 369, 2038-2057. 
https://doi.org/10.1098/rsta.2010.0328

[4] Megevand, C., Mosnier, A., Hourticq, J., Klas, S., Nina, D. and Streck, C. (2013) Dynamiques de déforestation dans le bassin du Congo: Réconcilier la croissance économique et la protection de la forêt. Banque mondiale, Washington DC, $201 \mathrm{p}$. https://doi.org/10.1596/978-0-8213-9827-2

[5] Barima, Y. (2009) Dynamique, fragmentation et diversité végétale des paysages forestiers en milieux de transition forêt-savane dans le département de Tanda (Côte d'Ivoire). Thèse de Doctorat, Université Libre de Bruxelles, Bruxelles.

[6] UNFCCC (2007) Rapport du deuxième atelier sur la réduction des émissions dues à la déforestation dans les pays en développement. FCCC/SBSTA/2007/3.

[7] MECNT (2010) R-PP République Démocratique du Congo, Version, 11 Janvier 2010 , p. 3.

[8] Houghton, R.A., House, J.I., Pongratz, J., Van der Werf, G., DeFries, R., Hansen, M.C., et al. (2012) Carbon Emissions from Land-Use and Land-Cover Change. Biogeosciences, 9, 5125-5142. https://doi.org/10.5194/bg-9-5125-2012

[9] FAO (2006) Etat des forêts du Bassin du Congo 2006, p. 84.

[10] DIAF (2015) Protocole méthodologique de l'évaluation du couvert forestier national de référence en République Démocratique du Congo. Document de travail. MECNT, Kinshasa, $34 \mathrm{p}$.

[11] Laporte, N.T., Stabach, J.A., Grosh, R., Lin, T.S. and Goetz, S. (2007) Expansion of Industrial Logging in Central Africa. Science, 316, 1451.

https://doi.org/10.1126/science.1141057

[12] Baccini, A., Goetz, S.J., Walker, W.S., Laporte, N.T., Sun, M., Sulla-Menashe, D., et al. (2012) Estimated Carbon Dioxide Emissions from Tropical Deforestation Improved by Carbon-Density Maps. Nature Climate Change, 2, 182-185. https://doi.org/10.1038/nclimate1354

[13] MECNT (2010) R-PP République Démocratique du Congo, Version Finale, Juillet 2010.

[14] UNDP/FAO (2010) The Synthesis Report Which Sets the National Consensus on the Drivers of Deforestation Was Based on Four Qualitative and Quantitative Studies. The Université Catholique de Louvain, Civil Society.

[15] Mayaux, P., Bartholome, E., Fritz, S. and Belward, A. (2004) A New Land-Cover Map of Africa for the Year 2000. Journal of Biogeography, 31, 861-877. https://doi.org/10.1111/j.1365-2699.2004.01073.x

[16] République démocratique du Congo (2011) Atlas interactif de la RDC, République démocratique du Congo/World Ressources Institute (WRI).

[17] De Wasseige, C., Devers, D., de Marcken, P., et al. (2009) Les forêts du bassin du Congo-État des forêts 2008, Luxembourg, Office des publications de l'Union européenne.

[18] Debroux, L., Hart, T., Kaimowitz, D., Karsenty, A. and Topa, G. (Eds.) (2007) La forêt en République démocratique du Congo post-conflit: Analyse d'un agenda prioritaire. xxii, $82 \mathrm{p}$.

[19] De Wasseige, C., Flynn, J., Louppe, D., HiolHiol, F. and Mayaux, P. (2014) The Forests of the Congo Basin-State of the Forest 2013. Publication Office of the European Union, ISBN: 978-92-79-22716-5.

[20] RDC (2018) Niveau d'Émissions de Référence des Forets pour la Réduction des Émissions dues a la Déforestation en République Démocratique du Congo.

[21] Shapiro, A., Thieme, M., Kamdem Toham, A., Sindorf, N. and Blom, A. (2009) 
Strategic Biodiversity Assessment for the Democratic Republic of Congo: Using a Decision Support System and Expert Review to Define Priority Areas for Conservation (Évaluation stratégique de la biodiversité de la République Démocratique du Congo: étayée par un système de soutien décisionnel et l'étude d'experts pour définir les zones prioritaires à des fins de conservation). WWF.

[22] FAO (2001) Global Forest Resources Assessment of 2000-Main Report. FAO Forestry Paper 140. FAO, Rome.

[23] Duveiller, G., Defourny, P., Desclee, B. and Mayaux, P. (2008) Deforestation in Central Africa: Estimates at Regional, National and Landscape Levels by Advanced Processing of Systematically-Distributed Landsat Extracts. Remote Sensing of Environment, 112, 1969-1981. https://doi.org/10.1016/j.rse.2007.07.026

[24] Ernst, C., Mayaux, P., Verhegghen, A., et al. (2013) National Forest Cover change in the Congo Basin: Deforestation, Reforestation, Degradation and Regeneration for the Years 1990, 2000 and 2005. Global Change Biology, 19, 1173-1187.

https://doi.org/10.1111/gcb.12092

[25] Potapov, P.V., Molinario, G., Hansen, M.C., Tyukavina, A., Stehman, S., Barker, B. and Humber, M. (2012) Quantification of Land Cover and Land Use within the Rural Complex of the Democratic Republic of Congo. Environmental Research Letters, 12, 104001. https://doi.org/10.1088/1748-9326/aa8680

[26] Hansen, M.C., Molinario, G. and Potapov, P.V. (2013) Forest Cover Dynamics of Shifting Cultivation in the Democratic Republic of Congo: A Remote Sensing-Based Assessment for 2000-2010. Environmental Research Letters, 10, 094009. https://doi.org/10.1088/1748-9326/10/9/094009

[27] MECNDD (2015) Protocole méthodologique et résultats de l'analyse de changement de couvert forestier 1990-2010 de la RDC. 